\title{
Enhanced trace Tl removal with ferrate through the addition of Mn(II) : Effect and Mechanism
}

Yu-Lei Liu, Yan-Ting Li, Lu Wang*, Wei Wang, Jun Ma

State Key Laboratory of Urban Water Resource and Environment, School of Environment, Harbin Institute of Technology, Harbin 150090, China

${ }^{*}$ Corresponding author: Lu Wang, e-mail: wanglu9195@163.com;

\section{Content:}

Detection accuracy of the employed ICP-MS on T1 detection (Figure S1);

Variation of residual Mn when different concentrations of Mn(II) co-added with Fe(VI)

for $\mathrm{Tl}$ removal (Figure S2);

Variation of $\mathrm{Fe}(\mathrm{VI})$ content in $\mathrm{Tl}$ removal process with $\mathrm{Fe}(\mathrm{VI})$ and $\mathrm{Fe}(\mathrm{VI})+\mathrm{Mn}(\mathrm{II})$ (Figure S3);

SEM analysis about the settlements formed in authentic Tl polluted water (Figure S4); XPS analysis of $\mathrm{Tl}$ in settlement formed in $\mathrm{Fe}(\mathrm{VI}) / \mathrm{Mn}$ (II) group at $\mathrm{pH}$ 6.0, 7.0 and 8.0 (Figure S5);

Distribution of $\mathrm{Tl}(\mathrm{I})$ and $\mathrm{Tl}(\mathrm{III})$ hydroxyl species as a function of solution $\mathrm{pH}$ (Figure S6);

FTIR spectra of the particles formed in $\mathrm{Fe}(\mathrm{VI})$ and $\mathrm{Fe}(\mathrm{VI})+\mathrm{Mn}(\mathrm{II})$ treatment group in the reaction with $\mathrm{Tl}$ (Figure S7); 
Analysis of the contribution of adsorption and oxidation to Tl removal (Figure S8). 

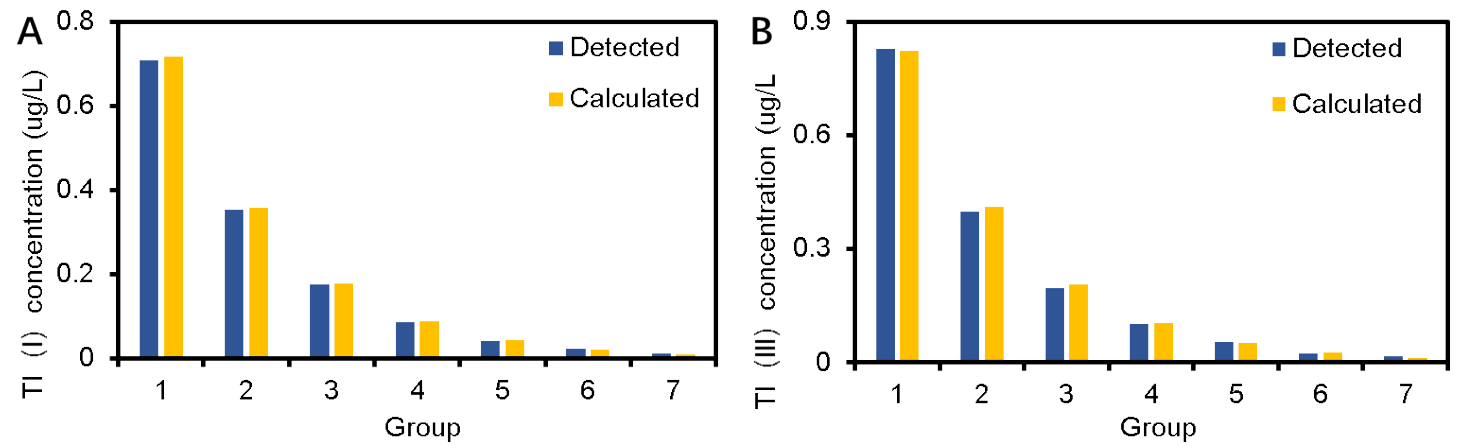

Figure S1. The ICP-MS detected (through serial 2-fold dilution) and theoretically calculated concentration of Tl(I) (A) and Tl(III) (B). 


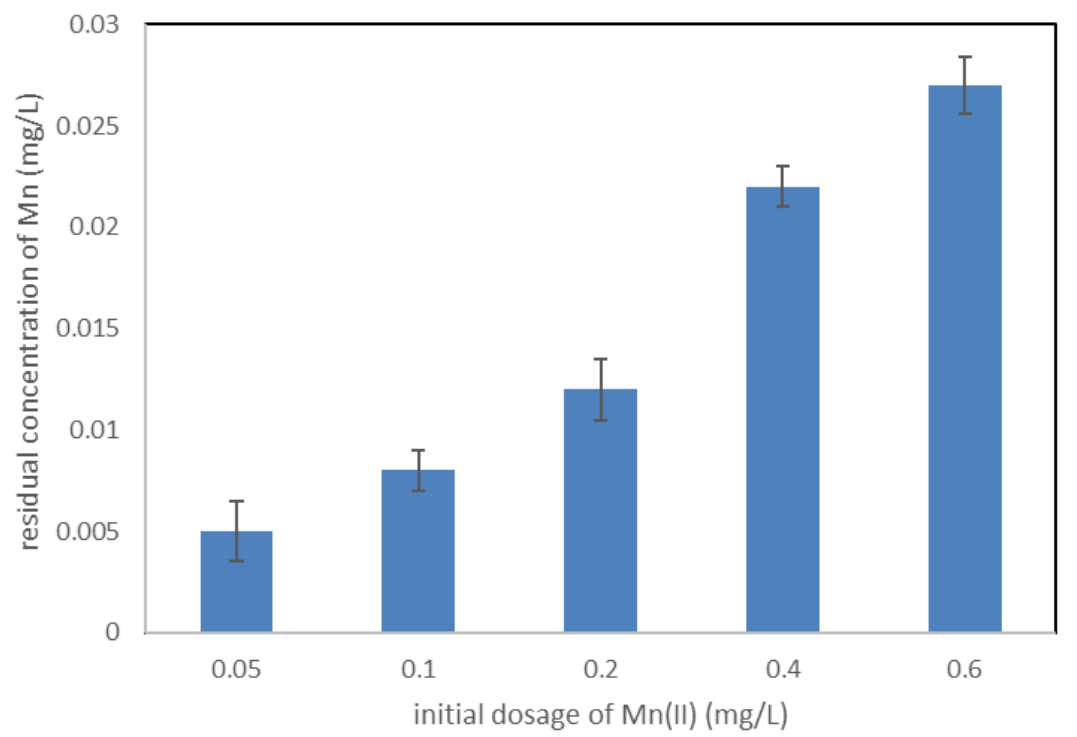

Figure S2. Variation of residual Mn when different concentrations $(0.05-0.6 \mathrm{mg} / \mathrm{L})$ of $\mathrm{Mn}(\mathrm{II})$ co-added with ferrate for Tl removal. Experimental conditions: $\mathrm{pH}=6.95 \sim 7.05$, $[\mathrm{Tl}(\mathrm{I})]_{0}=1 \mu \mathrm{g} / \mathrm{L},[\mathrm{Fe}(\mathrm{VI})]=0.5 \mathrm{mg} / \mathrm{L},\left[\mathrm{Na}_{2} \mathrm{CO}_{3}\right]=20 \mathrm{mM}, \mathrm{T}=20^{\circ} \mathrm{C}$ 


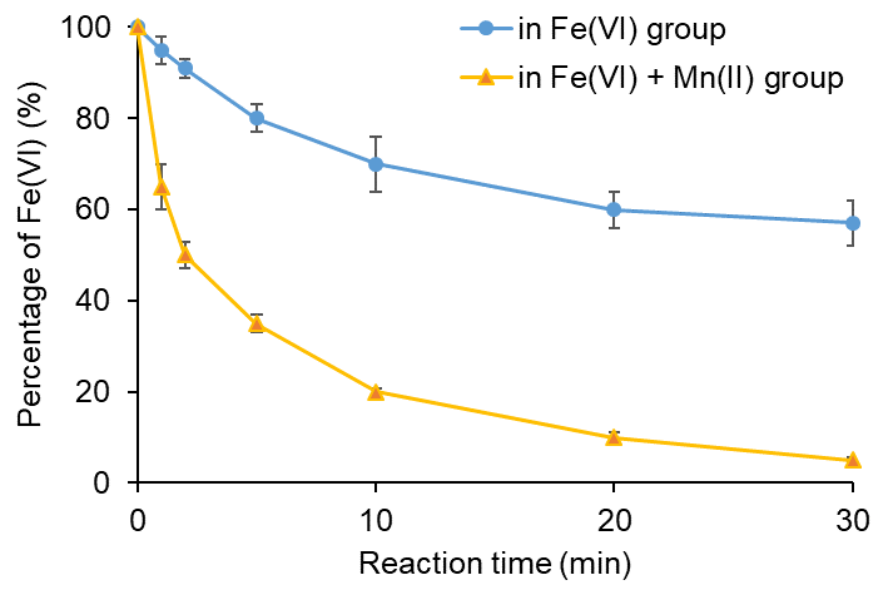

Figure S3. Variation of $\mathrm{Fe}(\mathrm{VI})$ content in the $\mathrm{Tl}$ removal process with $\mathrm{Fe}(\mathrm{VI})$ and $\mathrm{Fe}(\mathrm{VI})$

$+\mathrm{Mn}(\mathrm{II})$. Experimental condition: $[\mathrm{Tl}(\mathrm{I})]_{0}=1 \mu \mathrm{g} / \mathrm{L},[\mathrm{Fe}(\mathrm{VI})]_{0}=0.5 \mathrm{mg} / \mathrm{L},[\mathrm{Mn}(\mathrm{II})]_{0}=$ $50 \mu \mathrm{g} / \mathrm{L},\left[\mathrm{Na}_{2} \mathrm{CO}_{3}\right]=20 \mathrm{mM}, \mathrm{T}=20^{\circ} \mathrm{C}$. 

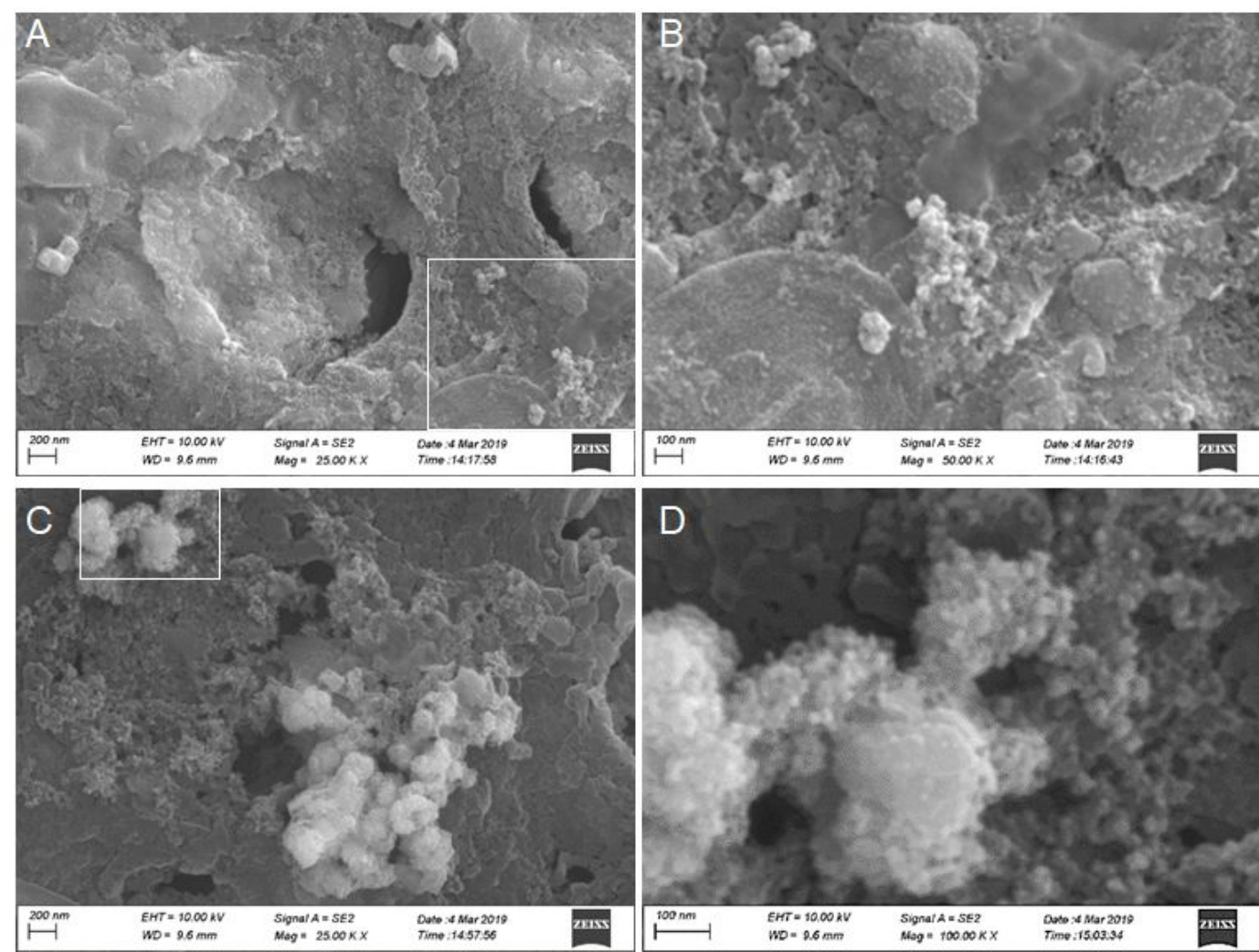

Figure S4. SEM analysis about the settlements formed after Fe(VI) $(0.5 \mathrm{mg} / \mathrm{L})$ treatment $(\mathrm{A}$ and $\mathrm{B})$ and $\mathrm{Fe}(\mathrm{VI})(0.5 \mathrm{mg} / \mathrm{L})+\mathrm{Mn}(\mathrm{II})(50 \mu \mathrm{g} / \mathrm{L})$ treatment $(\mathrm{C}$ and $\mathrm{D})$ of Tl polluted natural water (River water 1). 


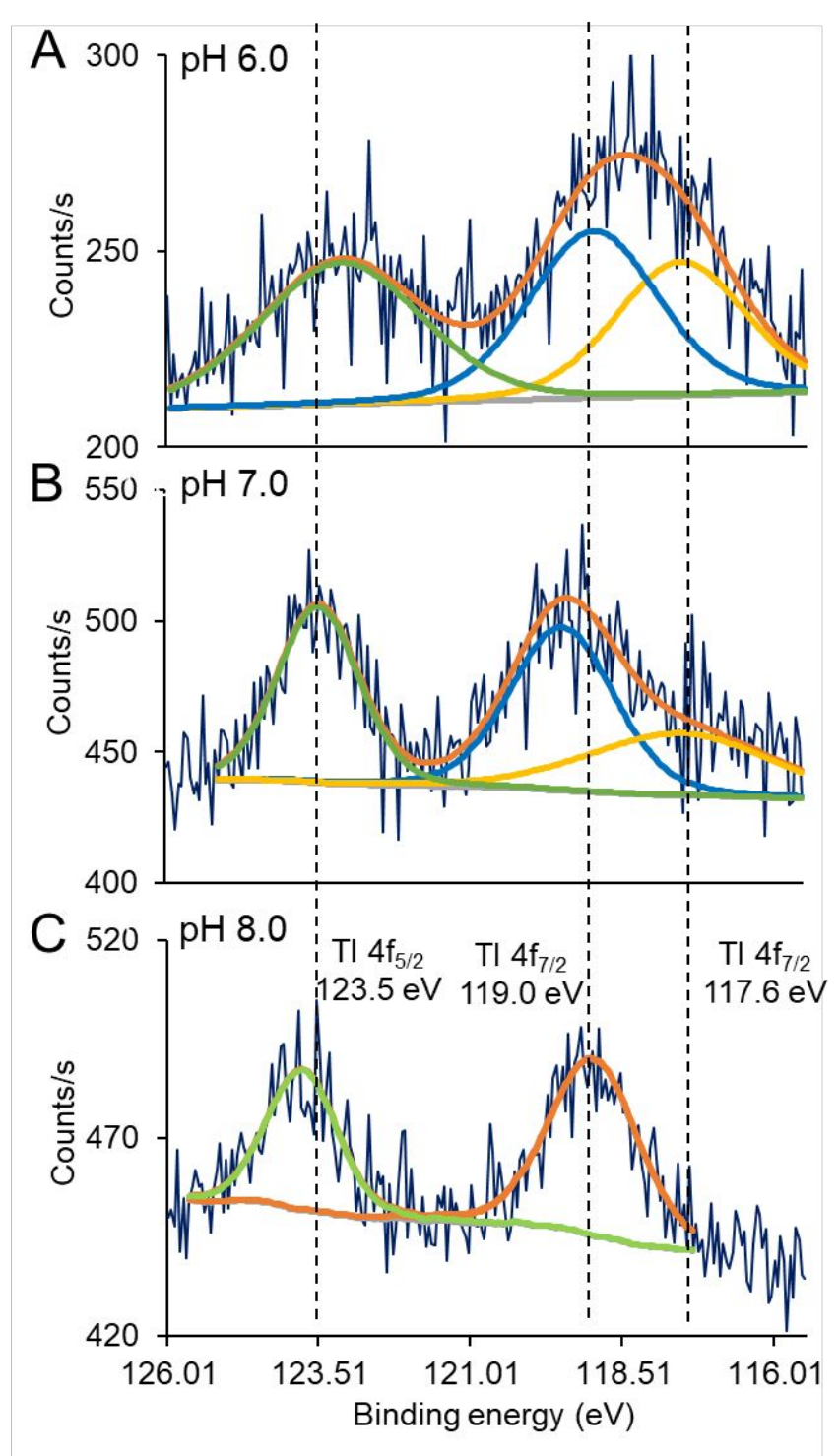

Figure S5. XPS spectra of $\mathrm{Tl}$ in settlement formed in $\mathrm{Fe}(\mathrm{VI}) / \mathrm{Mn}$ (II) group at $\mathrm{pH}$ 6.0,

7.0 and 8.0. Experimental condition: $[\mathrm{Tl}(\mathrm{I})]_{0}=1 \mu \mathrm{g} / \mathrm{L},[\mathrm{Fe}(\mathrm{VI})]_{0}=0.5 \mathrm{mg} / \mathrm{L},[\mathrm{Mn}(\mathrm{II})]_{0}$

$=50 \mu \mathrm{g} / \mathrm{L},\left[\mathrm{Na}_{2} \mathrm{CO}_{3}\right]=20 \mathrm{mM}, \mathrm{T}=20^{\circ} \mathrm{C}$. 

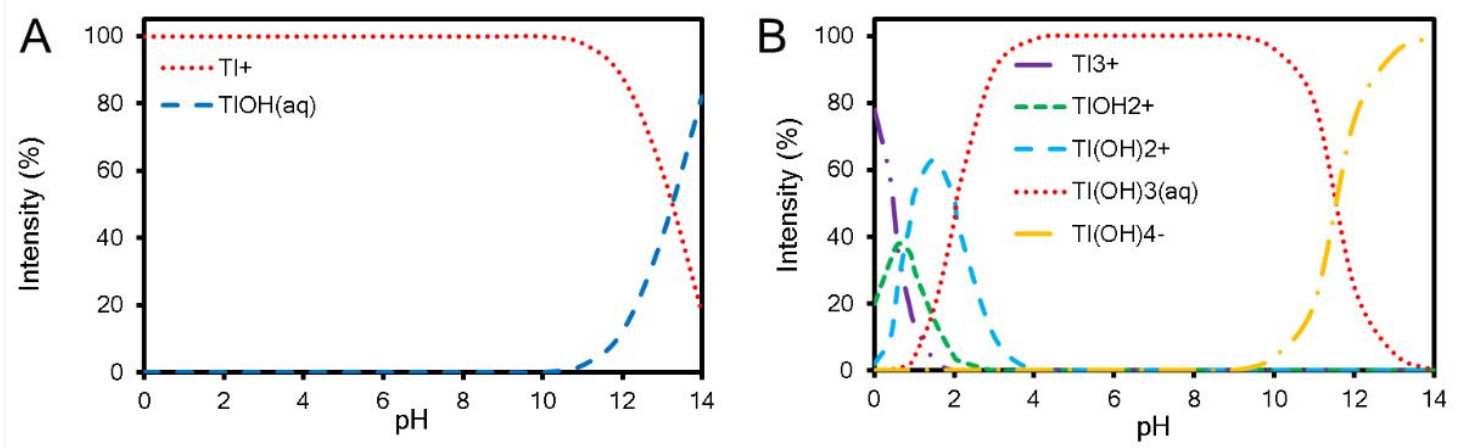

Figure S6. Distribution of Tl(I) hydroxyl species(A) and Tl(III) hydroxyl species (B) as a function of solution $\mathrm{pH}$ according to the published hydrolysis constants of $\mathrm{Tl}$ (Laforte et al. 2005). 


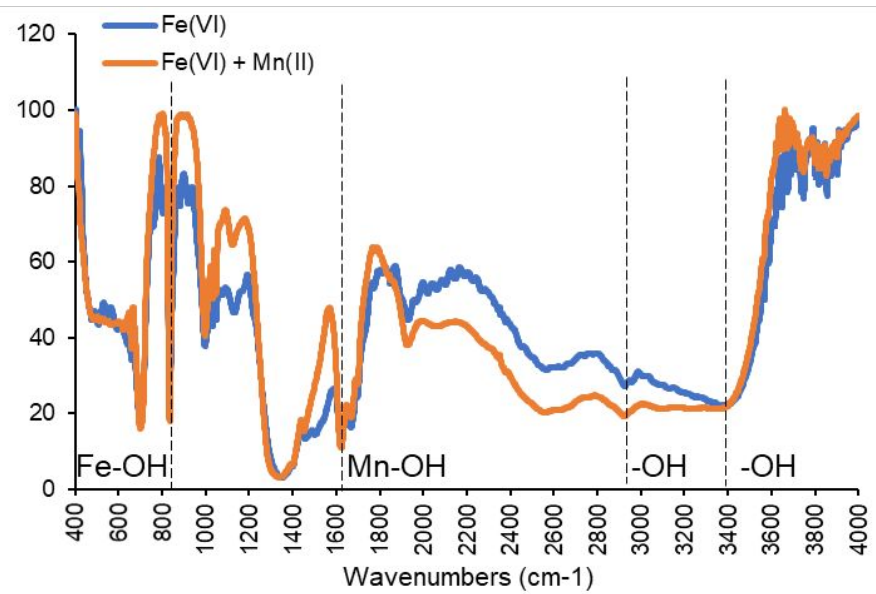

Figure S7. FTIR spectra of the particles formed in Fe(VI) (a) and $\mathrm{Fe}(\mathrm{VI})+\mathrm{Mn}(\mathrm{II})$ (b) treatment group in the reaction with Tl. Experimental condition: $[\mathrm{Tl}(\mathrm{I})]_{0}=1 \mu \mathrm{g} / \mathrm{L}$, $[\mathrm{Fe}(\mathrm{VI})]_{0}=0.5 \mathrm{mg} / \mathrm{L},[\mathrm{Mn}(\mathrm{II})]_{0}=50 \mu \mathrm{g} / \mathrm{L},\left[\mathrm{Na}_{2} \mathrm{CO}_{3}\right]=20 \mathrm{mM}, \mathrm{T}=20^{\circ} \mathrm{C}$. 


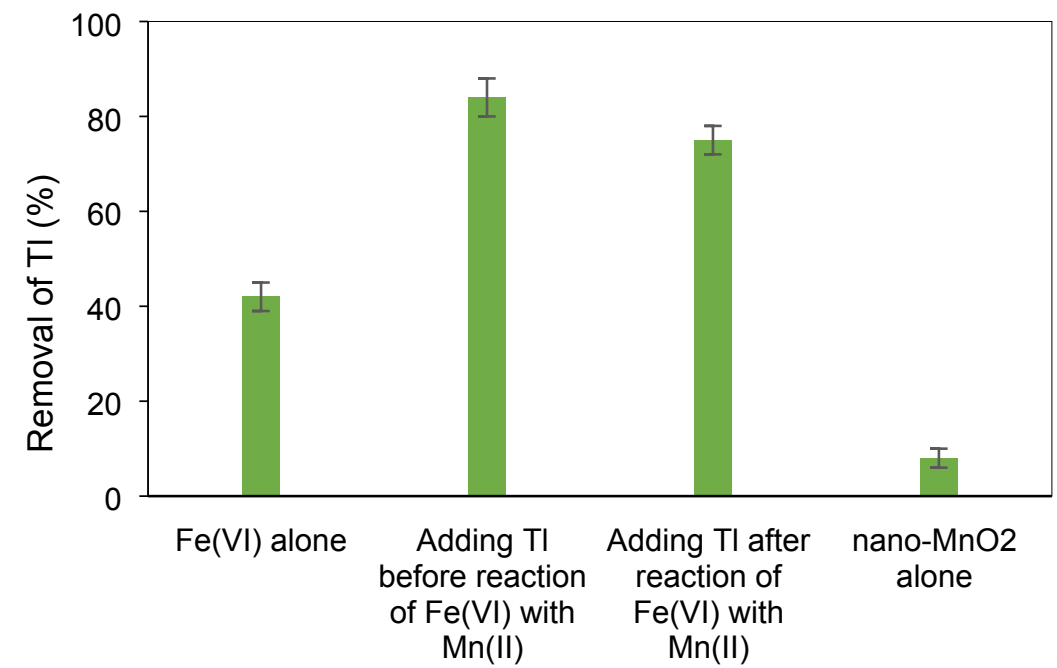

Figure S8. Analysis of the contribution of adsorption and oxidation to Tl removal.

Experimental conditions: $\mathrm{pH}=6.95 \sim 7.05,[\mathrm{Tl}(\mathrm{I})]_{0}=1 \mu \mathrm{g} / \mathrm{L},[\mathrm{Fe}(\mathrm{VI})]=0.5 \mathrm{mg} / \mathrm{L}$, $[\mathrm{Mn}(\mathrm{II})]=50 \mu \mathrm{g} / \mathrm{L},\left[\right.$ nano- $\left.-\mathrm{MnO}_{2}\right]=80 \mu \mathrm{g} / \mathrm{L}, \mathrm{T}=20^{\circ} \mathrm{C}$. 